\title{
Kecacingan pada saluran pencernaan monyet ekor panjang (Macaca fascicularis)
}

\author{
Rizky Diyu Purnama ${ }^{1}$, Risa Tiura ${ }^{2} *$, Huda Salahudin Darusman ${ }^{3}$ \\ ${ }^{1}$ Program Profesi Dokter Hewan, Fakultas Kedokteran Hewan, Institut Pertanian Bogor \\ ${ }^{2}$ Departemen Ilmu Penyakit Hewan dan Kesehatan Masyarakat Veteriner, Fakultas Kedokteran Hewan, \\ Institut Pertanian Bogor \\ ${ }^{3}$ Departemen Anatomi, Fisiologi, dan Farmakologi, Fakultas Kedokteran Hewan, Institut Pertanian Bogor
}

\begin{abstract}
ABSTRAK: Monyet ekor panjang (Macaca fascicularis) merupakan satwa primata yang sering ditangkarkan dan digunakan sebagai hewan coba terutama dalam pengujian vaksin dan obat. Salah satu gangguan kesehatan yang perlu diantisipasi dalam upaya penangkaran adalah kecacingan. Penelitian ini bertujuan untuk mengetahui jenis telur cacing dan derajat infeksi kecacingan pada monyet ekor panjang. Sampel feses dari 26 monyet ekor panjang diambil dan dianalisa meggunakan metode McMaster dan metode Kato-Katz. Hasil pemeriksaan menunjukkan 4 sampel feses ditemukan telur cacing Trichuris Sp. dan Strongylid dengan kategori derajat infeksi ringan.
\end{abstract}

\section{Kata Kunci:}

kecacingan, monyet ekor panjang, saluran pencernaan

\section{PENDAHULUAN}

Primata memiliki kemiripan secara fisiologis dan anatomis dengan manusia, primata sering ditangkarkan dan dijadikan hewan coba. Salah satu permasalahan yang dihadapi satwa primata di penangkaran adalah kecacingan (Dwipayanti et al. 2014). Kasus kecacingan pada saluran pencernaan merupakan penyakit yang sering dijumpai pada primata, termasuk didalamnya monyet ekor panjang (Schurer et al. 2019).

Telur cacing sebagai sumber infeksi dapat ditemukan pada feses segar monyet ekor panjang yang berada di alam maupun di kandang penangkaran (Schurer et al. 2019). Infeksi dapat ditularkan melalui berbagai aktivitas yang dilakukan oleh monyet ekor panjang. Primata ini merupakan hewan sosial yang hidup berkoloni sehingga penularan antar individu menjadi sangat besar. Umumnya pada kasus kecacingan gejala klinis yang ditimbulkan dari manifestasi cacing saluran pencernaan mampu menyebabkan penurunan penyerapan nutrisi dan dehidrasi (Dwipayanti et al. 2014). Infeksi kecacingan pada saluran pencernaan juga berdampak pada penurunan kekebalan tubuh sehingga infeksi sekunder oleh berbagai agen penyakit dalam jangka panjang memiliki risiko yang tinggi (Muller 2002). Identifikasi dan pemeriksaan telur cacing perlu dilakukan untuk mengetahui derajat infeksi kecacingan dan mengetahu jenis cacing yang menginfeksi untuk selanjutnya menjadi dasar penentuan pemberian obat cacing dan program pengendalian kecacingan yang tepat pada monyet ekor panjang (Macaca fascicularis).

\section{- BAHAN DAN METODE}

Penelitian ini menggunakan sampel feses 26 monyet ekor panjang yang diambil dari kandang individu dengan usia sampel kurang dari satu hari. Pemeriksaan sampel feses dilakukan secara kuantitatif menggunakan metode McMaster dan dilakukan secara kualitatif menggunakan metode apung (Thientpont et al. 1995) dan metode Kato-Katz (Levecke et al. 2011).

\section{- HASIL DAN PEMBAHASAN}

Hasil pemeriksaan secara kualitatif menunjukkan terdapat 4 sampel feses monyet ekor panjang (Macaca fascicularis) positif terdapat telur cacing. Berdasarkan hasil indentifikasi morfologi telur cacing yang ditemukan pada sampel feses tersebut adalah telur nematoda yaitu telur Trichuris Sp. dan Strongylid (Tabel 1). Dwipayanti et al. (2014) melaporkan jenis telur cacing Trichuris Sp. dan Strongylid pernah menginfeksi monyet ekor panjang.

Tabel 1. Jumlah telur tiap gram tinja (TTGT)

\begin{tabular}{|cc|}
\hline $\begin{array}{c}\text { Pemeriksaan Kualitatif } \\
\text { (jenis telur cacing) }\end{array}$ & $\begin{array}{c}\text { Rataan Hasil Pemeriksaan TTGT } \\
\text { (telur tiap gram tinja) }\end{array}$ \\
\hline Trichuris Sp. & 350 \\
Strongylid & 150 \\
\hline
\end{tabular}

Hasil pemeriksaan kuantitatif pada Tabel 1 menunjukkan jenis telur cacing Trichuris Sp. dan Strongylid pada feses

Diterima: 24-04-2021 | Direvisi: 17-05-2021 | Disetujui: 23-05-2021

(C) 2021 CC-BY-SA. Ini adalah artikel Open Access yang didistribusikan berdasarkan ketentuan dari Creative Commons Attribution ShareAlike 4.0 International License (https://creativecommons.org/licenses/by-sa/4.0/). 
monyet ekor panjang (Macaca fascicularis) memiliki rataan TTGT masing-masing sebesar 350 dan 150. Transmisi penyakit parasit secara langsung pada satwa primata dipengaruhi oleh populasi inang, kepadatan dan besar ukuran kelompok. Semakin besar populasi inang maka infeksi semakin tinggi dan beragam (Freeland 1979).

Berdasarkan hasil pemeriksaan TTGT monyet ekor panjang (Macaca fascicularis) tergolong mengalami infeksi kecacingan ringan. Menurut Thientpont et al. (1995) hewan yang terinfeksi dengan jumlah TTGT 1-499 dikategorikan mengalami infeksi ringan, Jumlag TTGT 500-5000 dikategorikan mengalami infeksi sedang dan jumlah TTGT lebih dari 5000 dikategorikan mengalami infeksi berat

\section{- SIMPULAN}

Hasil pemeriksaan telur cacing menunjukkan monyet ekor (Macaca fascicularis) panjang terinfeksi oleh dua jenis cacing yaitu Trichuris Sp. dan Strongylid dengan derajat infeksi kecacingan ringan.

\section{- INFORMASI PENULIS}

Penulis untuk Korespondensi

*RT: risati@apps.ipb.ac.id

Departemen Ilmu Penyakit Hewan dan Kesehatan Masyarakat Veteriner, Fakultas Kedokteran Hewan, Institut Pertanian Bogor. Jalan Agatis Kampus IPB Dramaga 16680, Dramaga, Bogor, Jawa Barat INDONESIA

\section{PUSTAKA ACUAN}

Dwipayanti KA, Oka IDM, Rompis ALT. 2014. Infeksi cacing saluran pencernaan monyet ekor panjang (Macaca fascicularis) yang diperdagangkan di Pasar Satria Denpasar. Buletin Veteriner Udayana. 6(1):59-66.

Freeland WJ. 1979. Primate social groups as biological island. Ecology 60(4): 719-728.

Levecke B, Behnke JM, Ajjampur SS, Albonico M, Ame SM, Charlier J, Geiger SM, Hoa NT, Kamwa Ngassam RI, Kotze AC, McCarthy JS. 2011. A comparison of the sensitivity and fecal egg counts of the McMaster egg counting and Kato-Katz thick smear methods for soiltransmitted helminths. PLoS Neglected Tropical Diseases. 5(6):e1201.

Muller R. 2002. Worm and Human Desease 2nd Edition. New York (US): CABI Publishing.

Schurer JM, Ramirez V, Kyes P, Tanee T, Patarapadungkit N, Thamsenanupap P, Trufan S, Grant ET, Garland-Lewis G, Kelley S, Nueaitong H. 2019. Long-tailed macaques (Macaca fascicularis) in urban landscapes: gastrointestinal parasitism and barriers for healthy coexistence in northeast Thailand. The American Journal of Tropical Medicine and Hygiene.100(2):357.

Thientpont DE, Rochette F, Vanparus OFJ. 1995. Diagnosing helminthiasis through coprological examination. New York (US): Aplton-Century-Croft. 